\title{
Optimisation of fermentation conditions in the production of ethanol from Palmer mango
}

\section{Otimização das condições de fermentação na produção de etanol a partir da manga Palmer}

\author{
Simone de Lima Côrtes ${ }^{1}$; Dionisio Borsato ${ }^{2}$; Marissa Kimura ${ }^{3}$; \\ Ivanira Moreira ${ }^{4}$; Olivio Fernandes Galão ${ }^{5}$; Sílvia Borba Costa $^{6}$;
}

\begin{abstract}
The objective of this work is to analyse the production potential and optimize the aqueous pulp extract of Palmer mangoes for the production of ethanol. The concentration of total sugars obtained was measured by phenol sulphuric acid method in the pulp and by chromatography; the results showed $83.33 \mathrm{gL}^{-1}$ and $80.51 \mathrm{gL}^{-1}$ respectively. By means of preliminary tests at $30^{\circ} \mathrm{C}$, it was established that the period of 10 hours presented the biggest yield of ethanol. This was followed by fermentation, with 13 tests and two repetitions in the central point, after which the samples were centrifuged to determine the alcohol content. The optimisation indicated a formula containing $3.0 \mathrm{gL}^{-1}$ of yeast extract, $8.0 \mathrm{gL}^{-1}$ of yeast, and $0.35 \mathrm{gL} \mathrm{L}^{-1}$ of $\mathrm{NH}_{4} \mathrm{H}_{2} \mathrm{PO}_{4}$, for an alcohol content of $34.5 \mathrm{gL}^{-1}$ with a yield of $88.27 \%$.Sugar cane juice, diluted under the same conditions, was also fermented and passed through the same procedures; however the resulting alcohol content of 35.68 $g L^{-1}$ with a yield of $70.74 \%$ proved to be inferior value to that presented when the aqueous extract of Palmer mango was used.
\end{abstract}

Keywords:Alcoholic Fermentation, Ethyl Acohol, Response Surface Methodology.

\section{Resumo}

O objetivo deste trabalho foi analisar o potencial de produção e otimização do extrato aquoso da polpa da manga Palmer para a produção de etanol. Foi determinada a concentração de açúcares totais, na polpa pelo método do fenol sulfúrico e por cromatografia, sendo o valor obtido de açúcares totais de $83,33 g L^{-1} \mathrm{e}$ $80,51 \mathrm{gL}^{-1}$, respectivamente. Por meio de ensaios preliminares a $30^{\circ} \mathrm{C}$, estabeleceu-se que o tempo de 10 horas apresentou o maior rendimento em etanol. Em seguida foi feita a fermentação, com 13 ensaios e duas repetições no ponto central, após, as amostras foram centrifugadas e o teor de álcool foi determinado. A otimização indicou uma formulação contendo $3,0 \mathrm{gL} \mathrm{L}^{-1}$ de extrato de levedura, $8,0 \mathrm{gL} \mathrm{L}^{-1}$ de levedura e 0,35 $g L^{-1}$ de $\mathrm{NH}_{4} \mathrm{H}_{2} \mathrm{PO}_{4}$, para um teor de álcool de $34,5 \mathrm{gL}^{-1}$ e rendimento de $88,27 \%$. O caldo da cana-deaçúcar, diluído nas mesmas condições, também foi fermentado e passou pelos mesmos procedimentos, mas o resultado do teor de álcool foi de $35,68 g L^{-1}$ com rendimento de 70,74\% valor inferior ao apresentado quando se utilizou o extrato aquoso da manga Palmer.

Palavras-chave: Fermentação Alcoólica. Álcool Etílico. Metodologia de Superfície de Resposta.

\footnotetext{
${ }^{1}$ Me. em Bioenergia - PPGB/CCE, UEL, Londrina, Pr, Brasil; E-mail: simonecortes01@ gmail.com

${ }^{2}$ Prof. Dr. Depo. de Química, UEL, Londrina, Pr, Brasil; E-mail: dborsato@uel.br

${ }^{3}$ Discente, Mestrado, PPGB/CCE, UEL, Londrina, Pr, Brasil; E-mail: marissa.kimura@ hotmail.com

${ }^{4}$ Técnico de laboratório, UEL, Londrina, Pr, Brasil; E-mail: ivanira@uel.br

${ }^{5}$ Prof. Dr. Depto. de Química, UEL, Londrina, Pr, Brasil; E-mail: galao@uel.br

${ }^{6}$ Técnico de laboratório, UEL, Londrina, Pr, Brasil; E-mail: sborcabr@uel.br
} 


\section{Introduction}

Ethanol raises the attention of researchers, companies and governments. This is due to price pressures and the prospect of depleting non-renewable sources of fossil fuels, as well as concerns over the emission of substances that compromise the environment (BASTOS, 2007). Brazil has taken leadership in the use of ethanol as an automotive biofuel in the international scene of carbon sequestration and mitigation of the greenhouse effect. This fuel, however, can be produced not only with sugarcane or corn, but also with another biomass that has a significant amount of sugar, which is one of the main requirements in the production of alcohol (SPACINO et al., 2013). However, the production of ethanol can be achieved from the aqueous pulp extract of some high sugar fruits that can be grown for this purpose or those that are discarded during regular production. Moreover, fruits contain sugar molecules formed by one or two monosaccharides, which are fermented by yeasts (FORTES et al., 2012; MAIA et al, 2014). The higher the sugar concentration in the biomass, the greater the amount of ethanol that is obtained, as its production occurs through yeast fermentation of sugars (CARDOSO et al., 2014). The mango (Mangifera indica L.), is one of the most sought after fruits in the world (FOLEGATTI et al., 2002). The Palmer variety is characterized by yellowish pulp with firm flesh, good flavor $\left(21.6^{0}\right.$ Brix) and little or no fiber. It is a fruit that has gained attention and has become preferred because of its sharp, sweet taste and its propensity for consumption. Another advantage of the variety is that it has a small core, which guarantees a consistent pulp and a better use of the fruit with a pulp/fruit ratio of $72 \%$, thin skin and medium fiber content (COSTA, 2004). The substrates must be adequate for the development of the microorganism and the purpose of its activity, which is to produce a particular substance. For better performance the composition of the medium must be able to meetthe requirements of the microorganism, such as $\mathrm{pH}$ level, temperature, asepsis or sterility among others (LIMA, 2001). Alcoholic fermentation is a biological process, yeast being its main agent, in which sugar is transformed into alcohol and carbon dioxide. The most used species in the production of alcohol is Saccharomyces cerevisiae.This yeast, when in contact with a medium containing glucose and under anaerobic conditions, produces ethyl alcohol and carbon dioxide, along with several other byproducts. During the fermentation process several factors can arise which may alter the ethyl alcohol production by interfering with the cellular activity of the yeast. The $\mathrm{pH}$ level plays an important role in fermentation, and in order to favor the development of yeasts it must be in the range of 4.5 to 5.5 (JONES, PAMMENT; GREENFIELD, 1981). Through experimental planning and the analysis of response surface it is possible to investigate the influence of the variables in a process, as well as the interaction between them, and arrive at the variable value that optimizes the results (SCHIRMANN, et al., 2018). Therefore, as the world demand for ethanol increases and Brazil continues to stand out as a leader in both fruit and ethanol production, this work proposes to determine the sugar concentration and the best conditions for the alcoholic fermentation process of the aqueous extract of the Palmer mango pulp for the production of ethanol, using response surface methodology.

\section{Materials and methods}

\section{Preparation of the sample}

The Palmer mango was peeled, stripped and transformed into an aqueous extract with the addition of 50\% distilled water in a low-speed blender and the fibers were separated with the aid of a sieve. The aqueous extract obtained after milling was packed in a plastic bottle and one portion was diluted with distilled water in the same proportion as the mangoes. Both were frozen in and kept in a freezer until the moment of the use in fermentation.

\section{Yeast}

Blocks of commercial yeast Saccharomyces cerevisiae (ITAIQUARA brand) were allowed to rest at room temperature $\left(25^{\circ} \mathrm{C}\right)$ for one hour. The inner part of the yeast was cut into small pieces until it became a powder and was added to the wort at the set time for fermentation.

\section{Nutritional Supplementation}

Yeast extract (Acumedia) and monobasic ammonium phosphate P.A. (Vetec) were used as source of nitrogen and phosphorus. Magnesium sulphate (Nuclear) and zinc sulphate (Anidrol) were added to the entire culture medium (CRUZ; BORZANI, 1980).

\section{Chromatography}

Sigma-Aldrich standard solutions of nysthosis, sucrose, glucose, fructose and maltose were used, along with an $8 \mu m$ particle RCM type REZEX column. Other accessories of the chromatograph were a Shimadzu LC20AT pump, SIL-20AC HT automatic injector, RID-10A 
Côrtes, S.L. ${ }^{1}$; Borsato, D. ${ }^{2}$; Kimura, M. ${ }^{3}$; Moreira, I. ${ }^{4}$; Galão, O.F. ${ }^{5}$; Costa, S.B. ${ }^{6}$

detector and a CTO-20AS oven. Ultra-pure Mili-Q sonicated water was used in the mobile phase. The analyses were processed in Shimadzu's LC Solutions software

\section{Determination of total sugars}

For the determination of total sugars, the Dubois et al. (1956) method was used with concentrated sulfuric acid (Vetec), $5 \%$ phenol solution (Vetec), and $0.1 \%(w / v)$ standard solution of glucose.

\section{Alcoholic fermentation}

To perform the fermentation, pre-sterilized $125 \mathrm{~mL}$ erlenmeyer flasks were used containing supplemented culture medium and yeast at concentrations defined by the experimental design (Table 1). The erlenmeyer flasks were closed with hydrophobic cotton and incubated for ten hours at a stabilized at $30^{\circ} \mathrm{C}$ temperature in an oven. After removal from the oven the samples were centrifuged for 10 minutes at maximum rotation $(4000 \mathrm{rpm})$, distilled, and the alcohol content was measured

\section{Determination of alcohol content}

The following solutions were used: $0.15 \mathrm{~N}$ sulphochromic solution containing potassium dichromate $\left(\mathrm{K}_{2} \mathrm{Cr}_{2} \mathrm{O}_{7}\right)$, sulfuric acid $\left(\mathrm{H}_{2} \mathrm{SO}_{4}\right)$ and distilled water; ferrous ammonium sulfate solution $\left[\mathrm{Fe}\left(\mathrm{NH}_{4}\right)_{2}\left(\mathrm{SO}_{4}\right)_{2} \cdot 6 \mathrm{H}_{2} \mathrm{O}\right]$. As an indicator, the solution used was orthophenanthroline, iron sulphate heptahydrate and distilled water. To determine the alcohol content, the Zimmerman method (1970) was used. A $1 \mathrm{~mL}$ aliquot of the fermentation was distilled in a Tecnal TE-012 microdistiller, to which water was added, yielding a 20 $m L$ sample that was placed in a $125 \mathrm{~mL}$ Erlenmeyer flask, followed by an addition of $5 \mathrm{~mL}$ of distilled water, 20 $m L$ (3.7 $\mathrm{g}$ of potassium dichromate, $280 \mathrm{~mL}$ of sulfuric acid and sufficient distilled water to make $500 \mathrm{~mL}$ ). The solution was allowed to stand for 25 minutes in a water bath at $60^{\circ} \mathrm{C}$. Then $0.5 \mathrm{ml}$ of orthophenanthroline indicator ( $1.45 \mathrm{~g}$ of orthophenanthroline, $0.69 \mathrm{~g}$ of ferrous sulfate heptahydrate and sufficient distilled water to make up to $100 \mathrm{~mL}$ ) was added to the solution. Shortly after it was titrated with ammoniacal ferrous sulfate solution $(67.55 \mathrm{~g})$, sulfuric acid $(10 \mathrm{~mL})$ and distilled water sufficient to reach $500 \mathrm{~mL}$, the alcohol content being expressed as $g L^{-1}$ (ZIMMERMAN, 1970).

\section{Alcohol Content}

The alcohol content $(E)$ was determined by equation (1) and the yield by equation (2)

$$
E\left(g L^{-1}\right)=k . V . N .\left(1-\frac{V_{a}}{V_{b}}\right),
$$

Where, $E\left(g L^{-1}\right)$ the alcohol content, $k$ is the value of 11.5 a theoretical constant; $V$ and $N$ refer to the volume and molarity of the potassium dichromate reagent respectively: $V_{a}$ is the volume of ammoniacal ferrous sulfate used in titration of the sample and $V_{b}$ is the volume of ammoniacal ferrous sulfate spent in the titration of the white

Yield $(\%)=\frac{\text { Content of alcohol obtained }}{\text { Maximum alcohol content }} .100$.

\section{Experimental design}

The incomplete factorial design $\left(3^{3}\right)$ of Box-Behnken was used to optimize the alcoholic fermentation conditions of the aqueous extract of the samples. The independent variables; $X_{1}, X_{2}$ and $X_{3}$, were respectively transformed into and coded into three levels of variation, with the restrictions presented in table 1 .

Table 1: Independent variables and levels of variation in $g L^{-1}$.

\begin{tabular}{cccc}
\hline Independent variables & \multicolumn{3}{c}{ Coded variables } \\
\hline & -1 & 0 & 1 \\
$X_{1}=$ Yeast extract & 1.50 & 2.50 & 3.50 \\
$X_{2}=\mathrm{NH}_{4} \mathrm{H}_{2} \mathrm{PO}_{4}$ & 0.30 & 0.35 & 0.40 \\
$X_{3}=$ Yeast & 2.00 & 6.00 & 10.00 \\
\hline
\end{tabular}

Source: The Author.

\section{Mathematical Model}

The function used was thus

$$
Y=\beta_{0}+\sum_{i=1}^{k} \beta_{i} x_{i}+\sum_{i=1}^{k} \beta_{i i} x_{i}^{2}+\sum_{i<j} \beta_{i j} x_{i} x_{j}+\varepsilon
$$

In this case, $Y$, represents the response function of the experimental data, $x_{1}, x_{2}$ and $x_{3}$ are coded independent variables, corresponding to the concentrations of yeast extract, yeast and $\mathrm{NH}_{4} \mathrm{H}_{2} \mathrm{PO}_{4}$ respectively, $\beta$ the estimated parameters and $\varepsilon$ the error observed (STATISTICA, 2009). 


\section{Results and discussions}

To identify and quantify the different types of sugars present in Palmer mango, a chromatography of the aqueous extract of its pulp was performed using the standards of nystose, sucrose, fructose, glucose and mannitol (Figure 1).

Figure 1: Chromatography of the standards of nystose, sucrose, fructose, glucose and mannitol.

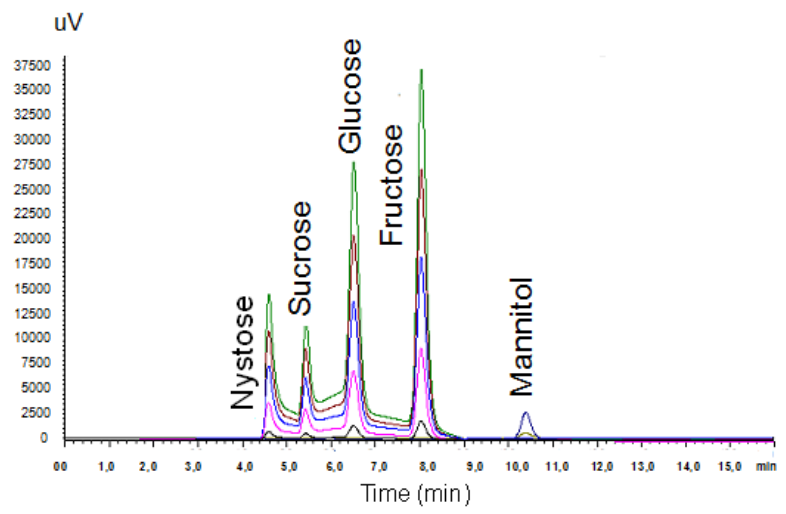

Source: The Author.

In the chromatographic analysis, the aqueous extract of the Palmer mango pulp (Figure 2) presented the following contents for the different types of sugars: nystose (3.0 $\left.g L^{-1}\right)$, sucrose $\left(40.71 g L^{-1}\right)$, glucose $\left(7.36 g L^{-1}\right)$, fructose $\left(16.93 \mathrm{gL}^{-1}\right)$ and polyalcohol mannitol (5.26 $\left.\mathrm{gL}^{-1}\right)$. Some compounds that were not identified reached the value of $7.24 \mathrm{gL}^{-1}$ and the sum of all compounds was $80.51 \mathrm{gL}^{-1}$.

Figure 2: Chromatogram of the aqueous extract of the Palmer mango with identification of the substances nystose, sucrose, glucose, fructose and mannitol.

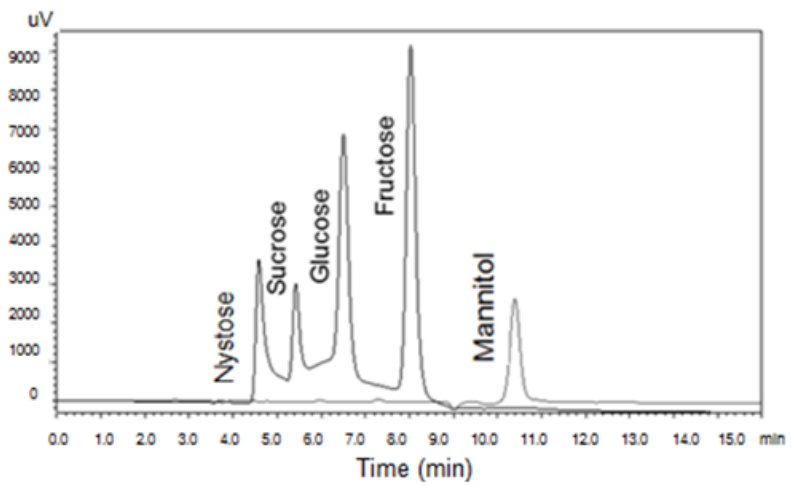

Source: The Author.

After the determination of the total sugars by the phenol sulphuric method $\left(83.33 g L^{-1}\right)$ and by chromatography $\left(80.51 \mathrm{gL}^{-1}\right)$, preliminary tests were carried out on the fermentation of the aqueous extract of the Palmer mango pulp to determine the fermentation time using the central point of delineation (Table 1). Figure 3 shows the progressive increase in alcohol production yield, where the points represent the experimental data and the continuous line the mathematically adjusted data. The polynomial model used showed the stabilization of the response values after 10 hours of fermentation, thus being determined as the best time period for the fermentation of the aqueous extract of the Palmer mango pulp.

Figure 3: Graph of the time $(h)$ of fermentation as a function of alcohol yield.

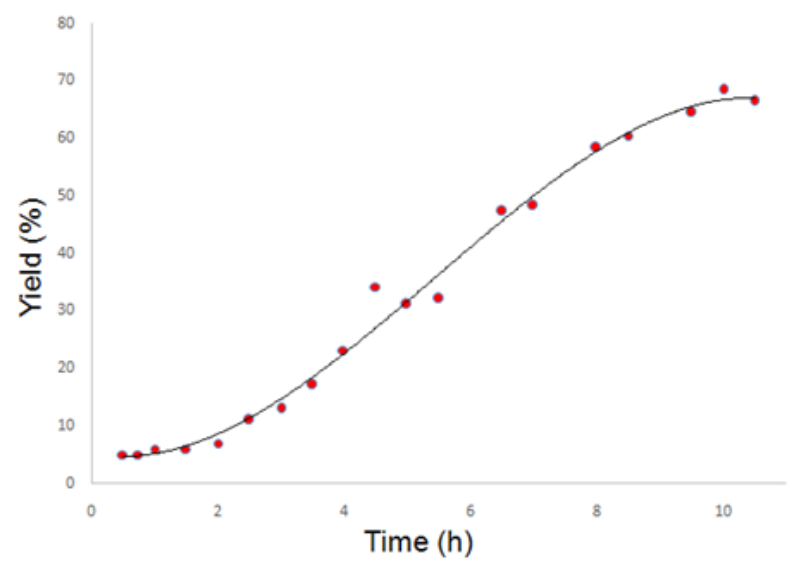

Source: The Author.

Identified the best time period, the incomplete factorial design of Box-Behnken $3^{3}$ was used in order to optimize the alcoholic fermentation of the aqueous extract of the Palmer mango pulp, with 13 experiments and two repetitions at the central point (CALADO, MONTGOMERY, 2003) Table 2 shows the coded independent variables, together with the levels of variation in original values, the production responses in $g L^{-1}$, and the yield in \%. Average values are presented of two repetitions of the fermentation tests, as well as the central point repetitions that were used to estimate error variance. The average central point in relation to the alcohol content of the aqueous extract of the Palmer mango was $33.98 \mathrm{gL}^{-1}$ and the yield was $88.27 \%$.

According to Table 3, the variance analysis indicated that the proposed model is significant at a $5 \%$ level. However the regression deviance is not significant at the same level of variation.

The quadratic model, containing the coded independent variables and adjusted for the yield of the alcoholic fermentation, is represented by equation 4 , where the regression coefficients $(\beta)$ were obtained by $\beta=$ $\left(A^{\prime} A\right)^{-1} A^{\prime} B$, where $A$ is the delineation matrix containing the linear, quadratic and interaction terms and $B$ is the response vector. 
Côrtes, S.L. ${ }^{1}$; Borsato, D. ${ }^{2}$; Kimura, M. ${ }^{3}$; Moreira, I. ${ }^{4}$; Galão, O.F. ${ }^{5}$; Costa, S.B. ${ }^{6}$

Table 2: Level of variation, original independent variables in $g L^{-1}$, alcohol content in $g L^{-1}$ and yield of the fermentation process in $\%$.

\begin{tabular}{|c|c|c|c|c|c|}
\hline Tests & & Independent variables & & $\begin{array}{c}\text { Alcohol Content } \\
\qquad\left(g L^{-1}\right)\end{array}$ & \\
\hline & $X_{1}$ & $X_{2}$ & $X_{3}$ & & \\
\hline & Yeast extrac & $\mathrm{NH}_{4} \mathrm{H}_{2} \mathrm{PO}_{4}$ & Yeast & & \\
\hline 1 & $-1(1.50)$ & $-1(0.30)$ & $0(0.60)$ & 28.62 & 74.36 \\
\hline 2 & $1(3.50)$ & $-1(0.30)$ & $0(0.60)$ & 31.36 & 81.49 \\
\hline 3 & $-1(1.50)$ & $1(0.40)$ & $0(0.60)$ & 29.02 & 75.38 \\
\hline 4 & $1(3.50)$ & $1(0.40)$ & $0(0.60)$ & 30.58 & 79.45 \\
\hline 5 & $-1(1.50)$ & $0(0.35)$ & $-1(2.00)$ & 25.61 & 66.55 \\
\hline 6 & $1(3.50)$ & $0(0.35)$ & $-1(2.00)$ & 28.23 & 73.34 \\
\hline 7 & $-1(1.50)$ & $0(0.35)$ & $1(10.00)$ & 30.58 & 79.45 \\
\hline 8 & $1(3.50)$ & $0(0.35)$ & $1(10.00)$ & 30.84 & 80.12 \\
\hline 9 & $0(2.50)$ & $-1(0.30)$ & $-1(2.00)$ & 27.71 & 71.98 \\
\hline 10 & $0(2.50)$ & $1(0.40)$ & $-1(2.00)$ & 25.61 & 66.54 \\
\hline 11 & $0(2.50)$ & $-1(0.30)$ & $1(10.00)$ & 29.79 & 77.41 \\
\hline 12 & $0(2.50)$ & $1(0.40)$ & $1(10.00)$ & 31.36 & 81.48 \\
\hline 13 & $0(2.50)$ & $0(0.35)$ & $0(0.60)$ & 32.93 & 85.55 \\
\hline 14 & $0(2.50)$ & $0(0.35)$ & $0(0.60)$ & 34.50 & 89.63 \\
\hline 15 & $0(2.50)$ & $0(0.35)$ & $0(0.60)$ & 34.50 & 89.63 \\
\hline
\end{tabular}

Source: The Author.

$$
\begin{array}{r}
Y=88.274^{*}+2.333^{*} x_{1}-0.298 x_{2}+5.006^{*} x_{3} \\
-0.766 x_{1} x_{2}-1.530 x_{1} x_{3}+2.375^{*} x_{2} x_{3} \\
-5,047 x_{1}^{2}-5.459^{*} x_{2}^{2}-8.362^{*} x_{3}^{2} .
\end{array}
$$

In the equation, asterisks represent the significant terms, at 5\% level, and Y represents the estimated yield of the fermentation reaction. In coded form, $x_{1}$ represents the concentration of yeast extract, $x_{2}$ the concentration of $\mathrm{NH}_{4} \mathrm{H}_{2} \mathrm{PO}_{4}$ and $x_{3}$ the yeast concentration. In addition, the coefficient of determination $\left(R^{2}\right)$ was equal to 0.98 and the adjusted coefficient equal to 0.95 , which can be considered adequate, as according to Joglekar and May (1987), to obtain a proper adjustment from the model to the experimental data the $R^{2}$ value must be greater than $80 \%$. The non-significant regression deviance $(p=0.95)$ and the high $R^{2}$ revealed that the obtained equation, without the non-significant terms, can be used for predictive purposes, showed itself to be useful for optimization procedures.

The Pareto chart (Figure 4) containing all terms shows the most significant variables and their order of importance

Figure 4: Pareto chart showing the most significant variables in the fermentation.

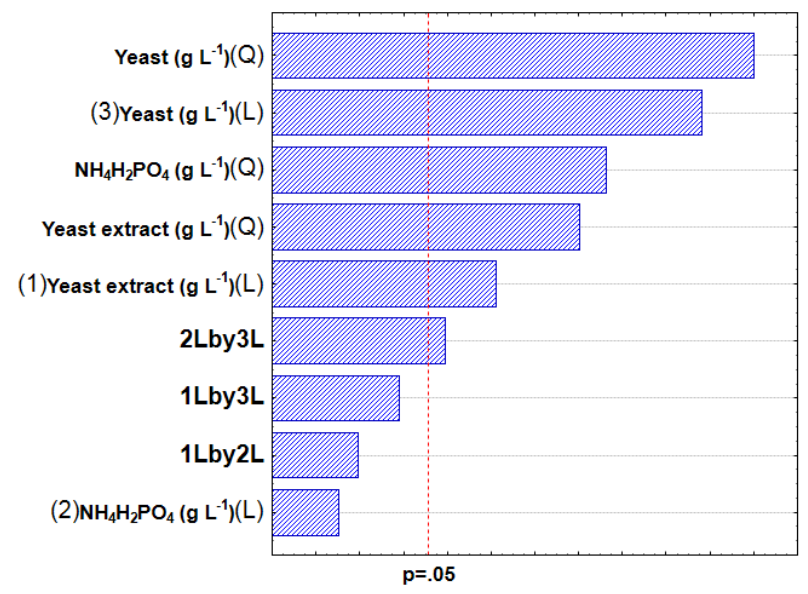

Source: The Author.

in the obtained predictive model. The values next to the rectangle represent the values of the t test statistics. The letter " $L$ " indicates the linear terms, the letter " $Q$ " the quadratic ones that do not present physical significance but give an indication of the graph's curvature. Through 
Table 3: Analysis of variance of the alcoholic fermentation reaction yield of the aqueous extract of the Palmer mango pulp, using the incomplete factorial design $3^{3}$.

\begin{tabular}{cccccc}
\hline Source of variation & $\mathrm{df}$ & Sum of squares & Mean square & $\mathbf{F}_{c a l}$ & $\mathbf{F}_{t a b}$ \\
\hline & $X_{1}$ & $X_{2}$ & $X_{3}$ & & \\
& Yeast extrac & $N_{4} H_{2} P O_{4}$ & Yeast & & \\
\hline Regression & 9 & 688.252 & 76.472 & $29.640^{*}$ & 4.77 \\
$X_{1}(L)$ & 1 & 43.545 & 43.545 & $16.878^{*}$ & 6.61 \\
$X_{2}(L)$ & 1 & 0.708 & 0.708 & $0.274^{(N S)}$ & 6.61 \\
$X_{3}(L)$ & 1 & 200.486 & 200.486 & $77.707^{*}$ & 6.61 \\
$X_{1}(Q)$ & 1 & 94.046 & 94.046 & $36.452^{*}$ & 6.61 \\
$X_{2}(Q)$ & 1 & 114.081 & 114.081 & $44.217^{*}$ & 6.61 \\
$X_{3}(Q)$ & 1 & 258.194 & 258.194 & $100.075^{*}$ & 6.61 \\
$X_{1} X_{2}$ & 1 & 2.344 & 2.344 & $0.909^{(N S)}$ & 6.61 \\
$X_{1} X_{3}$ & 1 & 9.361 & 9.361 & $3.628^{(N S)}$ & 6.61 \\
$X_{2} X_{3}$ & 1 & 22.564 & 22.564 & $8.746^{*}$ & 6.61 \\
Error & 5 & 12.898 & 2.580 & & \\
Total & 14 & 701.150 & & & \\
& & & & &
\end{tabular}

Source: The Author.

the graph it is possible to determine the most significant variables.

Figure 5 shows the optimization of the variables, showing a yield of $88.68 \%$ that can be obtained when using 8.0 $g L^{-1}$ of yeast, $2.5 g L^{-1}$ of yeast extract and $0.35 g L^{-1}$ of $\mathrm{NH}_{4} \mathrm{H}_{2} \mathrm{PO}_{4}$.

Figure 5: Optimization of the dependent and independent variables of the aqueous extract of the Palmer mango pulp.

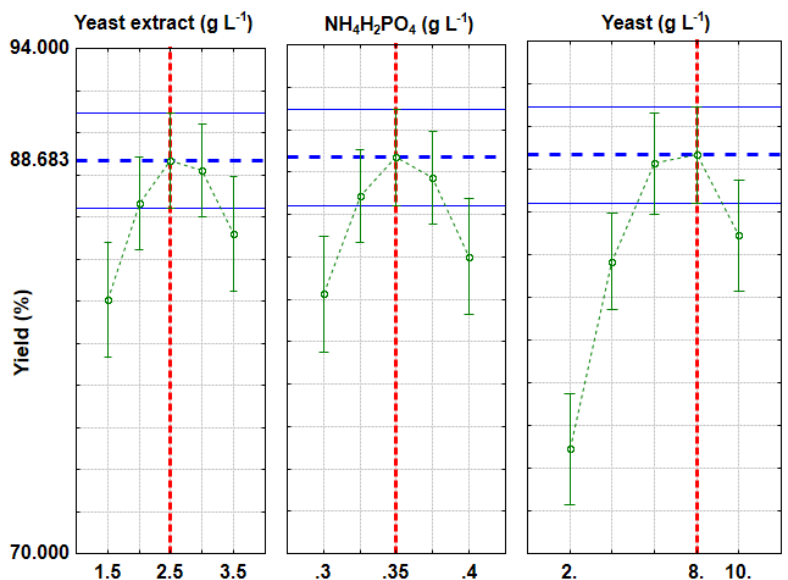

Source: The Author.

Figure 6 shows the level curves of the response surface, the binary combination between the original variables, yeast concentration $\left(g L^{-1}\right)$ and yeast extract $\left(g L^{-1}\right)$. On the diagram, one can easily see the contour regions of the response surface for the dependent variable, yield of alcohol production obtained by the mathematical model, and that the least significant linear variable $x_{2}\left(\mathrm{NH}_{4} \mathrm{H}_{2} \mathrm{PO}_{4}\right)$ in $0.35 \mathrm{gL}^{-1}$ was set according to the Pareto diagram (Figure 4). It was observed that the optimum region for the yield of ethanol production is close to the central point of the experimental design.

Figure 6: Level curves, Response surface, binary combination between original variables, yeast concentration $\left(g L^{-1}\right)$ and yeast extract $\left(g L^{-1}\right)$ and $\%$ alcohol yield.

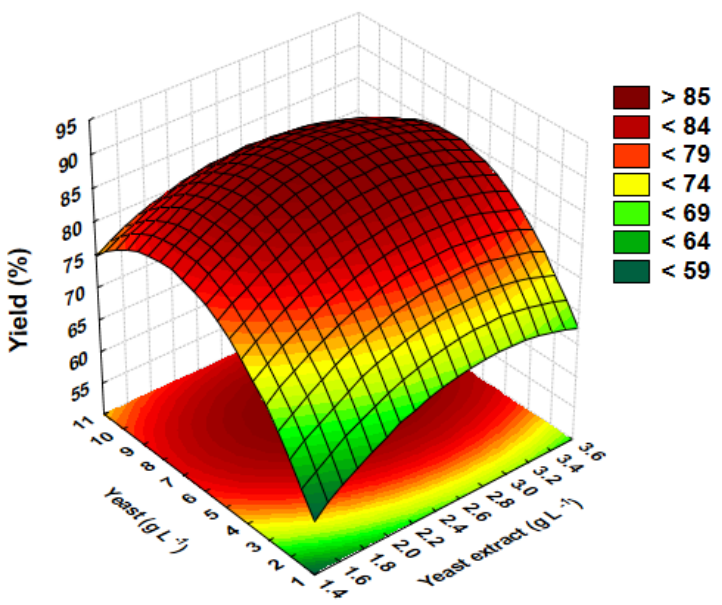

Source: Statistica (2009). 
Côrtes, S.L. ${ }^{1}$; Borsato, D. ${ }^{2}$; Kimura, M. ${ }^{3}$; Moreira, I. ${ }^{4}$; Galão, O.F. ${ }^{5}$; Costa, S.B. ${ }^{6}$

The validation of the predictive equation was achieved by fermentation of the aqueous extract of the Palmer mango pulp under optimum conditions. The average value of the triplicate yield was $88.27 \%$. Through the t-test, for simple sample, it was found that there was no significant difference at a level of $5 \%$ between this average value and that obtained in the optimization, which was $88.68 \%$. The result of the chromatographic analysis of the product before and after the fermentation (Figure 7) under the optimum conditions established, shows that although the fermentation took place satisfactorily, not all the sugars were consumed in their entirety.

Figure 7: Chromatograms overlap of the aqueous extract of the Palmer mango pulp, before and after the fermentation under optimum conditions, in 10 hours.

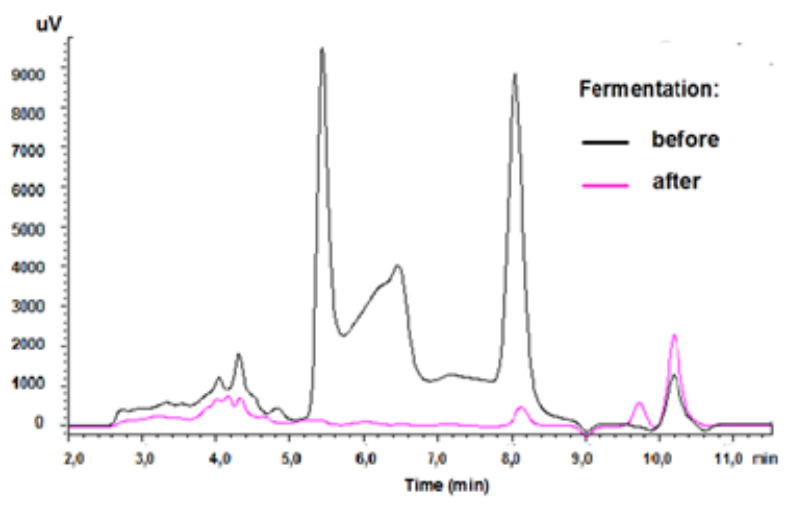

Source: The Author.

In order to obtain a comparison of the alcohol content in $g L^{-1}$ and the yield in \% of the Palmer mango, fermentation with sugarcane was also carried out, which in Brazil is a parameter in the production of alcohol. Through the refractometer, it was evaluated that the cane juice presented a reading of $19.8^{\circ}$ brix. Considering this value as the sugar concentration, its theoretical alcohol content after fermentation would be $101.26 \mathrm{gL}^{-1}$. Using the Zimmerman method (1970), the fermented broth was analyzed for ten hours in triplicate and its average was $28.62 \mathrm{gL}^{-1}$, thus the yield was $28.26 \%$. Dilution was also carried out in the proportion of 1 part juice and 1 part water, the soluble solids content being $9.9^{\circ}$ brix, yielding the theoretical alcohol content value of $50.63 g L^{-1}$. In the experiment with the diluted juice, the value obtained after fermentation of the alcohol content was on average $35.68 \mathrm{gL}^{-1}$, with a yield of around $70.74 \%$.

\section{Conclusion}

Palmer mango has shown itself to be an alternative in the production of alcohol, as it has favorable characteris- tics such as high sugar content, adequate $\mathrm{pH}$ and little or no fiber.

The fermentation of the aqueous extract of the Palmer mango pulp indicates that it can be used as an alternative source in alcohol production, if the values of $2.5 \mathrm{gL}$ of yeast extract, $0.35 \mathrm{gL}^{-1}$ of $\mathrm{NH}_{4} \mathrm{H}_{2} \mathrm{PO}_{4}$ and $8.0 \mathrm{gL}^{-1}$ of yeast are used at a constant temperature of $30^{\circ} \mathrm{C}$ for 10 hours. The diluted juice of sugarcane, which is the country's parameter in the production of alcohol, was fermented under the same conditions as the aqueous extract of the Palmer mango, and produced a lower alcohol content and yield, thus demonstrating that under the same conditions Palmer mangoes achieved more significant results than sugarcane in alcohol production.

\section{References}

BASTOS, V.D. Etanol, Alcooquímica e Biorrefinarias. BNDES Setorial, Rio de Janeiro, n. 25, p. 5-38, mar. 2007.

CALAdO, V.; MONTGOMERY, D. C. (Ed.). Planejamento de Experimentos usando o Statistica. Rio de Janeiro: E-papers Serviços Editoriais, 2003. 260 p.

CARDOSO, C.S.; SPACINO, K.R.; SILVA, E.T.; ANGILELLI, K.G.; GALÃO, O.F.; MOREIRA, I.; BORSATO, D. Application of the super-modified simplex optimization method in the fermentation of butiá palm (Butia eriospatha (Martius) beccari) aqueous extract. International Journal Of Environment and Bioenergy, Florida, v.9, n.2, p.130-142, 2014.

COSTA, J. C.; SANTOS, C. A. F. Cultivo da mangueira. Petrolina: Embrapa Semi-Árido. jul. 2004. (Sistemas de Produção, 2).

CRUZ, M.R.M.; BORZANI, W. Fermentação alcoólica de melaço e de caldo de cana de açúcar por Zymomonas: Ensaios preliminares. Revista Brasileira de Tecnologia, Brasilia, p. 51-57, 1980.

DUBOIS, M.; GILLES, K. A.; HAMILTON, J. K.; REBERS, P. A.; SMITH, F. Colorimetric method for determination of sugars and related substances. Analytical Chemistry, Washington, v. 28, n. 3, p. 350-356, 1956. https://doi .org/10.1021/ac60111a017.

FOLEGATTI, M. I. S.; MATSUURA, F. C. A. U.; TORREZAN, R.; BOTREL, N.; SOUZA FILHO, M. S. M.; AZEREDO, H. M. C.; BRITO, E. S.; SOUZA NETO, M. A. Processamento e produtos (manga). In: GENU, P.J. C.; PINTO, A. C. A cultura da mangueira. Brasília: Embrapa Informação Tecnológica. 2002. p. 409-431. 
FORTES, G.A.C.; NAVES, S.S.; FERRI, P.H.; SANTOS, S.C. Evaluation of Chemical Changes during Myrciaria cauliflora (Jabuticaba Fruit) Fermentation by $1 \mathrm{H}$ NMR Spectroscopy and Chemometric Analyses. Journal of Brazilian of Chemistry Society, São Paulo, v. 23, n. 10, p. 1815-1822, 2012. http://dx.doi.org/10. 1590/S0103-50532012005000050.

JOGLEKAR, A.M.; MAY, A.T. Product excellence through design of experiments. Cereals Foods World, London, v. 32, n.12, p.854-868, 1987.

JONES, R.P.; PAMMENT, N.; GREENFIELD, P.F. Alcohol fermentation by yeasts- the effect of environmental and other variables. Process Biochemistry, Vandoeuvre, v. 16, n. 3, p. 42-49, 1981.

LIMA, U. A. Aguardentes. In: AQUARONE, E. (Ed.). Biotecnologia industrial: alimentos e bebidas produzidos por fermentação. São Paulo: Edgard Blücher, 2001. v. 4, p.145-182.

MAIA, G.R.A., ANTUNES, S.R.M., WEIRICH, P.H., BORBA, S., COPPO, R.L., BORSATO, D. Optimisation of the alcoholic fermentation of aqueous jerivá pulp extract. Acta Scientiarum, v.36, n.4, p. 699-705, 2014. http://dx.doi.org/10.4025/ actascitechnol.v36i4.19559.

SCHIRMANN, J. G.; DEKKER, R. F. H.; BORSATO, D.; BARBOSA-DEKKER, A. M. Selective control for the laccase-catalyzed synthesis of dimers from 2,6dimethoxyphenol: optimization of 3,3',5,5'-tetramethoxybiphenyl-4,4'-diol synthesis using factorial design, and evaluation of its antioxidant action in biodiesel.Applied Catalysis A: General, Amsterdam, v. 555, n. 4, p. 88-97, 2018. https://doi.org/10.1016/j.apcata. 2018.02 .015 .

SPACINO, K. R.; SILVA, H.; ANGILELLI, K. G.; SILVA, E.; MOREIRA, I.; MESQUITA, M.; BORSATO, D. Using self-organizing map as a chemometric tool for alcohol classification by distillery. International Journal of Environment and Bioenergy, Weston, v.8, n.1, p.1-11, 2013.

ZIMMERMANN, H.W. (ED.). Studies on the dichromate method of alcohol determination. In: Methods in

Food Analysis. New York: Academic Press 1970. 